\title{
The prognosis of acute and persistent low-back pain: a meta-analysis
}

\author{
Luciola da C. Menezes Costa PhD, Christopher G. Maher PhD, Mark J. Hancock PhD, James H. McAuley PhD, \\ Robert D. Herbert PhD, Leonardo O.P. Costa PhD
}

See related commentary by Buchbinder and Underwood at www.cmaj.ca/lookup/doi/10.1503/cmaj.120627

\begin{abstract}
Background: Although low-back pain is a highly prevalent condition, its clinical course remains uncertain. Our main objective was to systematically review the literature on the clinical course of pain and disability in patients with acute and persistent low-back pain. Our secondary objective was to investigate whether pain and disability have similar courses.
\end{abstract}

Methods: We performed a meta-analysis of inception cohort studies. We identified eligible studies by searching MEDLINE, Embase and CINAHL. We included prospective studies that enrolled an episode-inception cohort of patients with acute or persistent low-back pain and that measured pain, disability or recovery. Two independent reviewers extracted data and assessed methodologic quality. We used mixed models to determine pooled estimates of pain and disability over time.

Results: Data from 33 discrete cohorts (11 166 participants) were included in the review. The variance-weighted mean pain score (out of a maximum score of 100) was 52 (95\% Cl 48-57) at baseline, $23(95 \% \mathrm{Cl} 21-25)$ at 6 weeks, 12 (95\% Cl 9-15) at 26 weeks and $6(95 \% \mathrm{Cl} 3-$ 10) at 52 weeks after the onset of pain for cohorts with acute pain. Among cohorts with persistent pain, the variance-weighted mean pain score (out of 100) was 51 (95\% Cl 44-59) at baseline, $33(95 \% \mathrm{Cl} 29-38)$ at 6 weeks, 26 $(95 \% \mathrm{Cl} 20-33)$ at 26 weeks and $23(95 \% \mathrm{Cl}$ 16-30) at 52 weeks after the onset of pain. The course of disability outcomes was similar to the time course of pain outcomes in the acute pain cohorts, but the pain outcomes were slightly worse than disability outcomes in the persistent pain cohorts.

Interpretation: Patients who presented with acute or persistent low-back pain improved markedly in the first six weeks. After that time improvement slowed. Low to moderate levels of pain and disability were still present at one year, especially in the cohorts with persistent pain.
$\mathrm{L}$ ow-back pain is a highly prevalent condition associated with work absenteeism, disability and large health care costs; however, there is still disagreement about prognosis. For example, the European guidelines for the management of low-back pain states that $90 \%$ of patients with acute low-back pain recover in six weeks. ${ }^{1}$ In contrast, some wellconducted cohort studies show a less optimistic picture, providing short-term estimates of recovery ranging from $39 \%$ to $76 \%$. ${ }^{2.3}$ This wide range of estimates of prognosis is likely explained by differences in cohorts and definitions used to define the onset or conclusion of an episode of low-back pain. Because very different definitions of recovery are often used, it is difficult to obtain pooled estimates of recovery rates. Instead, it might be more useful to describe the clinical course of low-back pain in terms of expected changes in pain or disability over time.
A recent systematic review ${ }^{4}$ summarized the prognostic factors for persistent disabling lowback pain but did not describe the clinical course. The only meta-analysis to investigate the clinical course of acute low-back pain was published in 2003. ${ }^{5}$ This review concluded that both pain and disability improve rapidly within weeks (mean reduction of $58 \%$ of initial scores in the first month) and recurrences are common. A limitation of this review was that, although it retrieved 15 studies, only 5 were cohort studies; the remaining 10 were randomized controlled trials. Randomized trials often have narrow inclusion criteria and low rates of participation, which make them less suitable for inferring prognosis. The best design to describe the prognosis of a condition is a cohort study enrolling a representative sample of incident cases (i.e., by including patients at a similar early point in their condition). ${ }^{6,7}$ Such studies are known as inception
Competing interests:

Christopher Maher has received grant funding from the National Health and Medical Research Council of Australia for the study of the prognosis of back pain.

He has also received supplementary funding from GlaxoSmithKline for an investigator-initiated trial of paracetamol for acute low-back pain. James McAuley has received salary funding from the National Health and Medical Research Council of Australia and has received funding from the George Institute for Global Health for attending conferences. No competing interests declared for Luciola Costa, Robert Herbert, Mark Hancock and Leonardo Costa.

This article has been peer reviewed.

Correspondence to: Christopher G. Maher, cmaher@georgeinstitute .org.au

CMAJ 2012. DOI:10.1503 /cmaj.111271 
cohort studies. To the best of our knowledge, no review has yet investigated the clinical course of pain and disability among people with persistent low-back pain (subacute and chronic). Thus, the prognosis for people with persistent low-back pain is still uncertain.

The aim of our study was to systematically review the clinical course of pain and disability in patients with acute and persistent low-back pain. We included only inception cohort studies. Our second aim was to investigate whether pain and disability have similar courses.

\section{Methods}

\section{Study selection}

We searched MEDLINE, CINAHL and Embase databases from 1950 to Nov. 22, 2011, to identify potentially eligible studies. The search strategy used the study population terms suggested by the Cochrane Back Review Group together with a strategy for searching MEDLINE for prognosis studies. The terms used to identify the study population included "low-back pain," "back pain" or "backache." Terms used to identify prognosis studies included "inception," "survival," "life tables," "log rank," "prospective" and "follow-up studies." The complete search strategies from all databases are included in Appendix 1 (available at www .cmaj.ca/lookup/suppl/doi:10.1503/cmaj.111271//DC1). Additionally, we performed a comprehensive examination of reference lists from eligible studies. We included only studies published in peer-reviewed journals. There were no language or geographic restrictions.

Two reviewers screened the titles and abstracts of each citation (Luciola Costa and Leo Costa). For each potentially eligible study, these authors obtained the full article and assessed whether the study fulfilled the inclusion criteria. In cases of disagreement, a third reviewer (C.M. or M.H.) was consulted and a decision was made by consensus. We defined low-back pain as pain or discomfort localized below the costal margins and above the inferior gluteal folds, with or without leg pain. Nonspecific low-back pain, the most common form of low-back pain, is a classification based on the exclusion of patients with a specific cause for their low-back pain (e.g., fracture, infection, cancer). It is sometimes called low-back pain of unknown origin. ${ }^{1,8}$

We included studies that were prospective cohort studies and that included a well-defined inception cohort (episode inception) of participants with low-back pain. Specifically, we included studies that had (a) acute and subacute low-back pain cohorts that included participants with nonspecific low-back pain of less than 12 weeks duration and/or (b) persistent low-back pain cohorts that included participants with nonspecific low-back pain for more than 12 weeks but less than 12 months. For inclusion, the studies had to report pain or disability outcomes or a global measure of recovery.

We excluded studies that included patients with specific diseases such as tumours, fractures, arthritis or cauda equina syndrome (but not sciatica).

\section{Data extraction}

For each cohort, the following summary data were obtained: sample source, sample size, inception time, outcomes (pain, disability and recovery rates) and duration of follow-up. Continuous outcomes (pain and disability) were converted to a common 0-100 scale. Recovery rates were based on the definitions used in the individual articles. If there were insufficient data presented in a study report, we contacted the authors to request these data.

We classified the study cohorts as acute lowback pain cohorts or persistent low-back pain cohorts. This classification was based on the mean or median duration of pain at study entry. If the cohort had a mean or median duration of pain at study entry of less than six weeks, it was classified as an acute low-back pain cohort. If the study had mean or median duration of pain at study entry for greater than or equal to six weeks, the study cohort was classified as a persistent low-back pain cohort. When means or medians were not available, we used the midpoint of the range of the inclusion criteria for pain duration. We also extracted data with regard to prognostic factors from all cohorts. Because of the high variability of prognostic factors investigated by each study and the different statistical approaches used, we extracted data for univariate analyses only.

\section{Quality assessment}

We rated the quality of the studies using an adaptation of the methodologic criteria suggested by Altman. ${ }^{6}$ These criteria relate to sampling (2 items), completeness of follow-up (2 items) and description of prognostic outcomes (1 item). The same criteria have been used in previous systematic reviews on the prognosis of acute low-back pain $^{5}$ and whiplash. ${ }^{9}$

\section{Statistical analysis}

We conducted a meta-analysis using the pain and disability outcome data. Pain and disability were modelled as a function of time. Time was treated in two ways. The first approach used the time of study entry as the reference time. We called this "inception time uncorrected." The second 
approach transformed the time data from each study by adding the mean or median inception time. We called this "inception time corrected." Inception time uncorrected analyses provide prognoses that would apply at the time of study entry, whereas inception time corrected analyses provide prognoses that would apply at the time of onset of acute or persistent low-back pain.

We obtained pooled estimates of the time course of pain and disability using linear mixed models. The mixed models included a random study-specific intercept to account for the dependence of repeated observations within studies. Each study was assigned a weight equal to the inverse of the mean variance of the estimates from that study. We modelled time as a continuous variable. Both pain and disability declined linearly with log time, so all analyses used log time as an independent variable. The reference time was considered to be day 1 .

The regression model was used to obtain pooled point and interval estimates of outcomes at baseline and at 6, 26 and 52 weeks. The exception was that estimates of baseline values were not obtained for analyses of inception time corrected because this involved extrapolating the fitted curves substantially beyond the range of the data. To test if pain and disability had a similar clinical course, we combined the pain and disability data and added to the model an additional covariate coded 0 for pain outcomes or 1 for disability outcomes.

\section{Results}

We screened 28613 potentially relevant studies

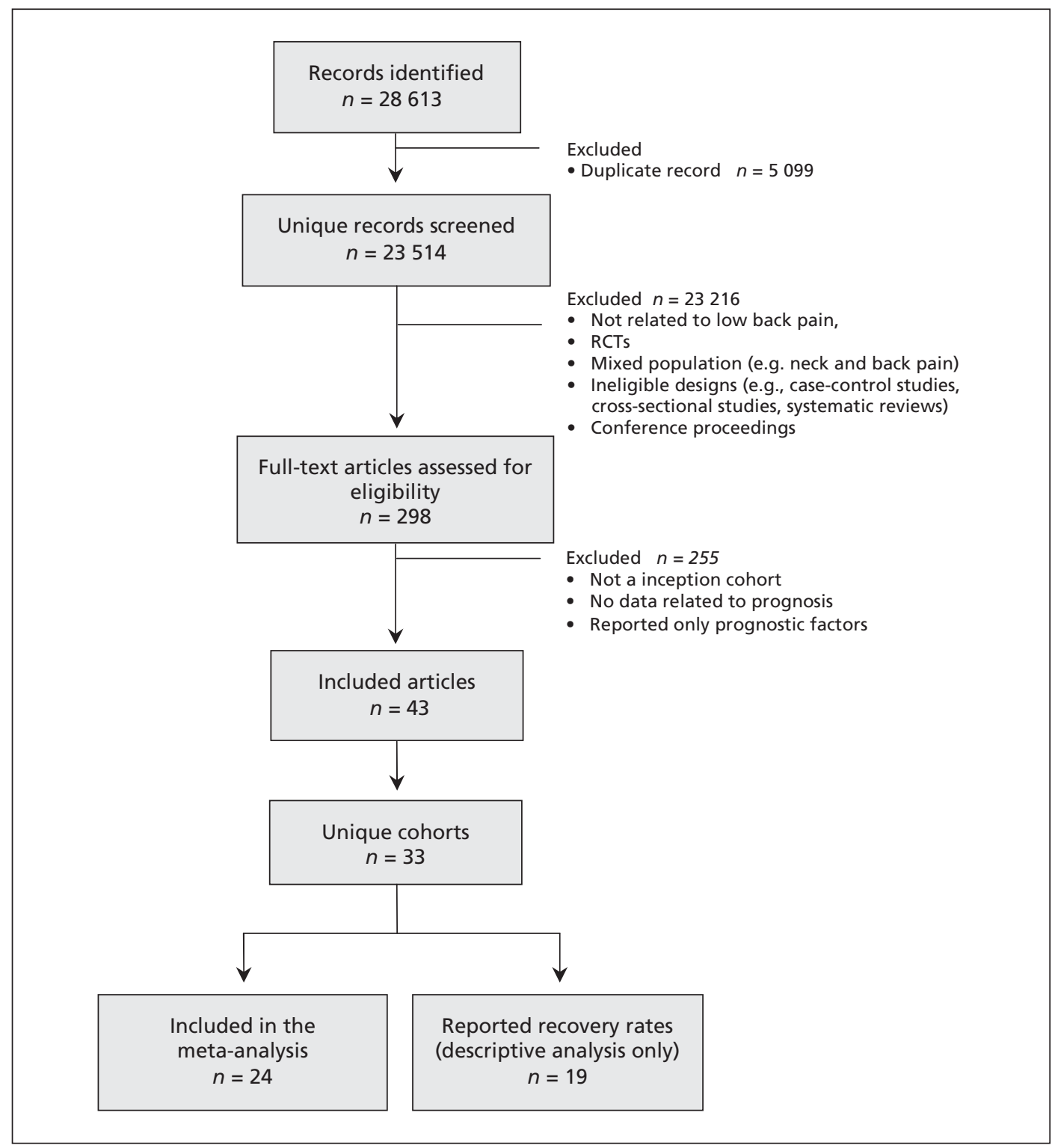

Figure 1: Selection of studies for inclusion in the systematic review. RCT = randomized controlled trials. 
and evaluated 298 full-text articles. Of these, 43 articles reporting 33 cohorts (11 166 participants) met all criteria and were included in the review
(Figure 1). The description of the included cohorts is presented in Table 1. Many reports contained insufficient data; we contacted the authors of 24

\begin{tabular}{|c|c|c|c|c|c|c|}
\hline Study & Source of participants & Area & $\begin{array}{l}\text { No. of } \\
\text { participants }\end{array}$ & $\begin{array}{l}\text { Onset of pain } \\
\text { before study } \\
\text { entry }\end{array}$ & Outcomes extracted & Follow-up \\
\hline Bakker et al. ${ }^{10}$ & General practitioner & $\begin{array}{l}\text { Nether- } \\
\text { lands }\end{array}$ & 97 & $<6 w k$ & $\begin{array}{l}\text { Pain (NRS 0-10), recovery } \\
\text { rates }\end{array}$ & $6 \mathrm{mo}$ \\
\hline Breen et al. $^{12}$ & $\begin{array}{l}\text { Two primary care trust } \\
\text { localities }\end{array}$ & England & 75 & $<12$ wk & $\begin{array}{l}\text { Pain (NRS 0-10), disability } \\
\text { (RMDQ 0-24) }\end{array}$ & $8 w k$ \\
\hline $\begin{array}{l}\text { Carey et al. }{ }^{13} \\
\text { Sundararajan } \\
\text { et al. } .^{14}\end{array}$ & $\begin{array}{l}\text { Urban and rural primary } \\
\text { care and chiropractors, } \\
\text { orthopedic and } \\
\text { neurosurgeons, and health } \\
\text { maintenance organization } \\
\text { providers }\end{array}$ & US & 1633 & $<10 w k$ & Recovery rates & $\begin{array}{l}2,4,8,12 \\
\text { and } 24 \text { wk }\end{array}$ \\
\hline Costa et al. ${ }^{16}$ & $\begin{array}{l}\text { Primary care practitioners } \\
\text { (general practitioners, } \\
\text { physiotherapists and } \\
\text { chiropractors) }\end{array}$ & Australia & 406 & $12 \mathrm{wk}$ & $\begin{array}{l}\text { Pain }(1-6) \text {, disability }(1-5) \text {, } \\
\text { recovery Rates }\end{array}$ & $\begin{array}{l}9 \text { and } 12 \\
\text { mo }\end{array}$ \\
\hline Coste et al. ${ }^{17}$ & Primary care practitioners & France & 103 & $<72 \mathrm{hr}$ & $\begin{array}{l}\text { Pain (VAS 0-100); } \\
\text { disability (RMDQ 0-24), } \\
\text { recovery rates }\end{array}$ & $\begin{array}{l}8,15 \mathrm{~d} \text { and } \\
1,2 \text { and } 3 \\
\text { mo }\end{array}$ \\
\hline Faber et al. ${ }^{23}$ & $\begin{array}{l}\text { General practitioners and } \\
\text { occupational health } \\
\text { physicians }\end{array}$ & $\begin{array}{l}\text { Nether- } \\
\text { lands }\end{array}$ & 103 & $3-12 w k$ & None & 3 and $6 \mathrm{mo}$ \\
\hline $\begin{array}{l}\text { Ferguson } \\
\text { et al. } .^{24,25}\end{array}$ & $\begin{array}{l}\text { Primary and urgent care } \\
\text { facilities }\end{array}$ & US & 32 & $<4 \mathrm{wk}$ & $\begin{array}{l}\text { Pain (0-5), disability (VAS } \\
0-150) \text {, recovery rates }\end{array}$ & $\begin{array}{l}2,4,6,8 \\
10 \mathrm{wk} \text { and } \\
6 \mathrm{mo}\end{array}$ \\
\hline Gatchel et al. ${ }^{26,27}$ & $\begin{array}{l}\text { Industrial medicine clinic } \\
\text { and orthopedic practices }\end{array}$ & US & 421 & $<6 w k$ & None & $\begin{array}{l}6 \text { and } 12 \\
\text { mo }\end{array}$ \\
\hline Grotle et al. ${ }^{2,28}$ & $\begin{array}{l}\text { Primary health care } \\
\text { providers }\end{array}$ & Norway & 123 & $<3 w k$ & $\begin{array}{l}\text { Pain (NRS 0-10), disability } \\
\text { (RMDQ 0-24), recovery } \\
\text { rates. }\end{array}$ & $\begin{array}{l}1,2,3 \text { and } \\
4 \text { wk and } 3, \\
6,9 \text { and } 12 \\
\text { mo }\end{array}$ \\
\hline Gurcay et al. ${ }^{29}$ & $\begin{array}{l}\text { Tertiary care referral } \\
\text { hospital }\end{array}$ & Turkey & 99 & $<3 w k$ & Recovery rates & $\begin{array}{l}1,2,4,8 \\
\text { and } 12 \mathrm{wk}\end{array}$ \\
\hline $\begin{array}{l}\text { Hasenbring } \\
\text { et al. } .^{30}\end{array}$ & $\begin{array}{l}\text { General or orthopedic } \\
\text { practitioners }\end{array}$ & Germany & 177 & $<12$ wk & $\begin{array}{l}\text { Pain (NRS 0-10), disability } \\
\text { (PDI 0-10) }\end{array}$ & $6 \mathrm{mo}$ \\
\hline
\end{tabular}


studies $^{2,3,11-23,26-35,37-39,42-44,46,49}$ and received additional

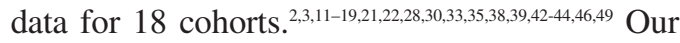
pooled analyses are based on summary data from 24 cohorts (4994 participants).

\section{Methodologic quality}

Almost all of the studies $(97 \%)$ provided suffi- cient definition of the sample: $17(51.5 \%)$ studies explicitly described methods for assembling a representative sample. In total, 24 (72.7\%) cohorts had a follow-up of at least $80 \%$, and $87.9 \%$ of cohorts had a follow-up for at least one prognosis outcome at three months or longer (Table 2).

Table 1 (part 2 of 2): Characteristics of the included studies

\begin{tabular}{|c|c|c|c|c|c|c|}
\hline Study & Source of participants & Area & $\begin{array}{c}\text { No. of } \\
\text { participants }\end{array}$ & $\begin{array}{l}\text { Onset of pain } \\
\text { before study } \\
\text { entry }\end{array}$ & Outcomes extracted & Follow-up \\
\hline $\begin{array}{l}\text { Hazard et al. }{ }^{31} \\
\text { Reid et al. } .^{32}\end{array}$ & $\begin{array}{l}\text { Vermont Department of } \\
\text { Labor and Industry }\end{array}$ & US & 166 & $\begin{array}{l}\text { within } 11 \mathrm{~d} \\
\text { of low-back } \\
\text { pain }\end{array}$ & None & $3 \mathrm{mo}$ \\
\hline $\begin{array}{l}\text { Heneweer } \\
\text { et al. }{ }^{33}\end{array}$ & $\begin{array}{l}\text { Primary care physical } \\
\text { therapy centres }\end{array}$ & $\begin{array}{l}\text { Nether- } \\
\text { lands }\end{array}$ & 66 & $<12$ wk & $\begin{array}{l}\text { Pain (VAS 0-100), } \\
\text { Disability (QBPDQ } \\
0 \%-100 \%) \text {, recovery rates }\end{array}$ & $\begin{array}{l}2,4,8 \text { and } \\
12 \mathrm{wk}\end{array}$ \\
\hline Henschke et al. ${ }^{3}$ & $\begin{array}{l}\text { Primary care practitioners } \\
\text { (general practitioners, } \\
\text { physiotherapists and } \\
\text { chiropractors) }\end{array}$ & Australia & 969 & $\begin{array}{l}>24 \text { h but }<2 \\
\text { wk }\end{array}$ & $\begin{array}{l}\text { Pain (1-6), disability }(1-5) \text {, } \\
\text { recovery rates }\end{array}$ & $\begin{array}{l}6 \mathrm{wk}, 3 \text { and } \\
12 \mathrm{mo}\end{array}$ \\
\hline $\begin{array}{l}\text { Klenerman } \\
\text { et al. }{ }^{34}\end{array}$ & General practitioners & England & 300 & $<1 \mathrm{wk}$ & Recovery rates & $\begin{array}{l}2 \text { and } 12 \\
\text { mo }\end{array}$ \\
\hline Koleck et al. ${ }^{35}$ & General practitioner & France & 99 & $10-90 d$ & $\begin{array}{l}\text { Pain (VAS 0-10), recovery } \\
\text { rates }\end{array}$ & $12 \mathrm{mo}$ \\
\hline Kovacs et al. ${ }^{36}$ & Primary care centres & Spain & 366 & $<12 \mathrm{wk}$ & $\begin{array}{l}\text { Pain (VAS 0-10), disability } \\
\text { (RMDQ 0-24) }\end{array}$ & $\begin{array}{l}2 \text { wk and } 8 \\
\text { wk }\end{array}$ \\
\hline $\begin{array}{l}\text { Lehmann } \\
\text { et al. }{ }^{37}\end{array}$ & Occupational physicians & US & 60 & $2-6$ wk & None & $6 \mathrm{mo}$ \\
\hline Melloh et al. ${ }^{38}$ & Primary care settings & $\begin{array}{l}\text { New } \\
\text { Zealand }\end{array}$ & 62 & $<12 \mathrm{wk}$ & $\begin{array}{l}\text { Pain (NRS 0-100), } \\
\text { disability (ODI 0-100), } \\
\text { recovery rates, }\end{array}$ & $\begin{array}{l}3,6,12 \mathrm{wk} \\
\text { and } 6 \mathrm{mo}\end{array}$ \\
\hline $\begin{array}{l}\text { Poiraudeau } \\
\text { et al. }{ }^{39}\end{array}$ & Rheumatologist & France & 443 & $4-12$ wk & $\begin{array}{l}\text { Pain (4-points), disability } \\
\text { (QBPDQ 0-20), recovery } \\
\text { rates }\end{array}$ & $3 \mathrm{mo}$ \\
\hline Reeser et al. ${ }^{40}$ & $\begin{array}{l}\text { Primary and tertiary care } \\
\text { facilities }\end{array}$ & US & 368 & $<6 \mathrm{wk}$ & $\begin{array}{l}\text { Disability (MODEMS } \\
0-100)\end{array}$ & $\begin{array}{l}6 \mathrm{wk}, 3 \text { and } \\
12 \mathrm{mo}\end{array}$ \\
\hline $\begin{array}{l}\text { Schiottz- } \\
\text { Christensen } \\
\text { et al. }{ }^{41}\end{array}$ & General practices & Denmark & 524 & $<14 \mathrm{~d}$ & Recovery rates & $\begin{array}{l}1,6 \text { and } 12 \\
\text { mo }\end{array}$ \\
\hline Shaw et al. ${ }^{42-44}$ & $\begin{array}{l}\text { Community-based } \\
\text { occupational health clinics }\end{array}$ & US & 568 & $<2 \mathrm{wk}$ & $\begin{array}{l}\text { Pain (VAS 0-10), disability } \\
\text { (RMDQ 0-100) }\end{array}$ & 1 and $3 \mathrm{mo}$ \\
\hline Sieben et al. ${ }^{45}$ & General practices & $\begin{array}{l}\text { Nether- } \\
\text { lands and } \\
\text { Belgium }\end{array}$ & 44 & $<2 w k$ & Disability (RMDQ 0-24) & $\begin{array}{l}2 \mathrm{wk}, 3 \text { and } \\
12 \mathrm{mo}\end{array}$ \\
\hline Sieben et al. ${ }^{46}$ & General practices & $\begin{array}{l}\text { Nether- } \\
\text { lands }\end{array}$ & 222 & $<3 w k$ & $\begin{array}{l}\text { Pain (VAS 0-100), } \\
\text { disability (QBPDQ 0-100) }\end{array}$ & $\begin{array}{l}3,6 \text { and } 12 \\
\text { mo }\end{array}$ \\
\hline Suri et al. ${ }^{47}$ & Outpatient clinics & US & 77 & $<12 \mathrm{wk}$ & $\begin{array}{l}\text { Pain (NRS 0-10), disability } \\
\text { (ODI 0-100) }\end{array}$ & $6 \mathrm{wk}$ \\
\hline $\begin{array}{l}\text { Swinkels- } \\
\text { Meewisse et al. }{ }^{48}\end{array}$ & $\begin{array}{l}\text { General practitioners and } \\
\text { physiotherapists }\end{array}$ & $\begin{array}{l}\text { Nether- } \\
\text { lands }\end{array}$ & 555 & $<4 \mathrm{wk}$ & $\begin{array}{l}\text { Pain (VAS 0-100), } \\
\text { disability (RMDQ 0-24) }\end{array}$ & $\begin{array}{l}6 \mathrm{wk} \text { and } 6 \\
\text { mo }\end{array}$ \\
\hline Thomas et al. ${ }^{49}$ & Community-based & US & 43 & $<4 w k$ & $\begin{array}{l}\text { Pain (McGill), disability } \\
\text { (RMDQ 0-24) }\end{array}$ & $\begin{array}{l}3,6 \text { and } 12 \\
\text { wk }\end{array}$ \\
\hline Valat et al. ${ }^{50}$ & $\begin{array}{l}\text { General practitioner and } \\
\text { rheumatologist }\end{array}$ & France & 2493 & $<1 \mathrm{wk}$ & Recovery rates & $\begin{array}{l}7 \pm 1 \text { wk of } \\
\text { follow-up }\end{array}$ \\
\hline
\end{tabular}


Clinical course of pain and disability

Twenty-one cohorts reported pain outcomes. Fifteen cohorts $2,3,10-12,17,18,24,25,28,30,36,42,43,44,46-49$ were classified as acute low-back pain cohorts and six $^{16,19-22,33,35,38,39}$ were persistent low-back pain cohorts. Twenty-two cohorts reported disability scores from at least one follow-up point: 16 of these were acute low-back pain cohorts $^{2,3,11,12,17,18,24,25,28,30,36,40,42-49}$ and 6 were persistent low-back pain cohorts. $15,16,19,20,21,22,33,38,39$ Pain and disability data are shown in Figures 2 and 3 . In the acute pain cohorts, the inception time uncorrected variance-weighted mean $(95 \%$ confidence interval $[\mathrm{CI}]$ ) pain score (out of a

Table 2: Methodologic quality assessment of included cohorts

\begin{tabular}{|c|c|c|c|c|c|}
\hline Study & Defined sample* & $\begin{array}{l}\text { Representative } \\
\text { samplet }\end{array}$ & $\begin{array}{l}\text { Follow-up rate } \\
\quad>80 \% \ddagger\end{array}$ & Follow-up time§ & Prognosisq \\
\hline Bakker et al. ${ }^{10}$ & Yes & No & Yes & Yes & Yes \\
\hline Bousema et al. ${ }^{11}$ & Yes & No & Yes & Yes & Yes \\
\hline Breen et al..$^{12}$ & Yes & No & No & No & No \\
\hline $\begin{array}{l}\text { Carey et al. }{ }^{13} \\
\text { Sundararajan et al. }{ }^{14}\end{array}$ & Yes & Yes & Yes & Yes & Yes \\
\hline Carey et al..$^{15}$ & Yes & Yes & No & Yes & Yes \\
\hline Costa et al..$^{16}$ & Yes & Yes & Yes & Yes & Yes \\
\hline Coste et al. ${ }^{17}$ & Yes & Yes & Yes & Yes & Yes \\
\hline Coste et al..$^{18}$ & Yes & Yes & Yes & Yes & Yes \\
\hline $\begin{array}{l}\text { Epping-Jordan et al. }{ }^{19} \\
\text { Shaw et al. } .^{20} \\
\text { Wahlgren et al. } .^{21} \\
\text { Williams et al. }{ }^{22}\end{array}$ & Yes & Yes & Yes & Yes & Yes \\
\hline Faber et al. ${ }^{23}$ & Yes & Yes & Yes & Yes & Yes \\
\hline Ferguson et al. ${ }^{24,25}$ & Yes & No & Yes & Yes & Yes \\
\hline Gatchel et al. ${ }^{26,27}$ & Yes & No & No & Yes & No \\
\hline Grotle et al. ${ }^{2,28}$ & Yes & No & Yes & Yes & Yes \\
\hline Gurcay et al..$^{29}$ & Yes & Yes & Yes & Yes & Yes \\
\hline Hasenbring et al..$^{30}$ & Yes & Yes & Yes & Yes & Yes \\
\hline $\begin{array}{l}\text { Hazard et al. } \\
\text { Reid et al. }\end{array}$ & No & Yes & Yes & Yes & Yes \\
\hline Heneweer et al..$^{33}$ & Yes & Yes & Yes & Yes & Yes \\
\hline Henschke et al. ${ }^{3}$ & Yes & Yes & Yes & Yes & Yes \\
\hline Klenerman et al..$^{34}$ & Yes & No & No & Yes & Yes \\
\hline Koleck et al. ${ }^{35}$ & Yes & Yes & Yes & Yes & Yes \\
\hline Kovacs et al. ${ }^{36}$ & Yes & No & Yes & No & Yes \\
\hline Lehmann et al. ${ }^{37}$ & Yes & No & Yes & Yes & Yes \\
\hline Melloh et al. ${ }^{38}$ & Yes & Yes & Yes & Yes & Yes \\
\hline Poiraudeau et al..$^{39}$ & Yes & Yes & Yes & Yes & Yes \\
\hline Reeser et al. ${ }^{40}$ & Yes & Yes & No & Yes & Yes \\
\hline Schiottz-Christensen et al. ${ }^{41}$ & Yes & No & Yes & Yes & Yes \\
\hline Shaw et al. ${ }^{42-44}$ & Yes & No & Yes & Yes & Yes \\
\hline Sieben et al..$^{45}$ & Yes & No & No & Yes & Yes \\
\hline Sieben et al..$^{46}$ & Yes & No & No & Yes & Yes \\
\hline Suri et al. ${ }^{47}$ & Yes & Yes & No & No & Yes \\
\hline Swinkels-Meewisse et al. ${ }^{48}$ & Yes & No & No & Yes & Yes \\
\hline Thomas et al. ${ }^{49}$ & Yes & No & Yes & Yes & No \\
\hline Valat et al..$^{50}$ & Yes & No & Yes & No & Yes \\
\hline \multicolumn{6}{|c|}{$\begin{array}{l}\text { *Description of source of patients and inclusion and exclusion criteria. } \\
\text { +Participants were selected as consecutive cases. } \\
\text { fOutcome data were available for at least } 80 \% \text { of participants at one follow-up point. } \\
\text { \$At least one prognostic outcome was followed up at three months or later. } \\
\text { IRaw data, percentages, survival rates or continuous outcome reported. }\end{array}$} \\
\hline
\end{tabular}


maximum of 100) was 52 (95\% CI 48-57) at baseline, 23 (95\% CI 21-25) at 6 weeks, 12 (95\% CI 9-15) at 26 weeks and 6 (95\% CI $3-$ 10) at 52 weeks after entering the study. In the cohort with persistent pain, the score was 51 (95\% CI 44-59) at baseline, 33 (95\% CI 2938 ) at 6 weeks, 26 (95\% CI 20-33) at 26 weeks and 23 (95\% CI 16-30) at 52 weeks. The estimates of pain and disability (inception time corrected and uncorrected) in the acute and persistent low-back pain cohorts are shown in Table 3.

\section{Within-study variation}

The standard deviation of pain or disability outcomes was typically about 20 points on a 100 point scale. This was true for pain and disability outcomes, for acute and persistent back pain and for short-term and longer-term outcomes. This is indicative of a moderate degree of person-toperson variability in outcomes.

\section{Between-study variation}

We used two statistics to quantify betweenstudy variability. The first was tau, which is a model-derived estimate of the standard deviation of outcomes on day 1 . The second measure of between-study variability was rho, the proportion of the total variance due to between-study variation on day 1 . For the inception time uncorrected analyses, betweenstudy variability was moderate: tau ranged from 8 to 14 and rho ranged from 0.60 to 0.73 . For the inception time corrected analyses, between-study heterogeneity was moderate to high, particularly for the disability outcome: tau ranged from 14 to 22 and rho ranged from 0.65 to 0.97 .

\section{Comparison of the clinical course of pain and disability}

The clinical course of pain and disability in the acute low-back pain cohorts was similar and the

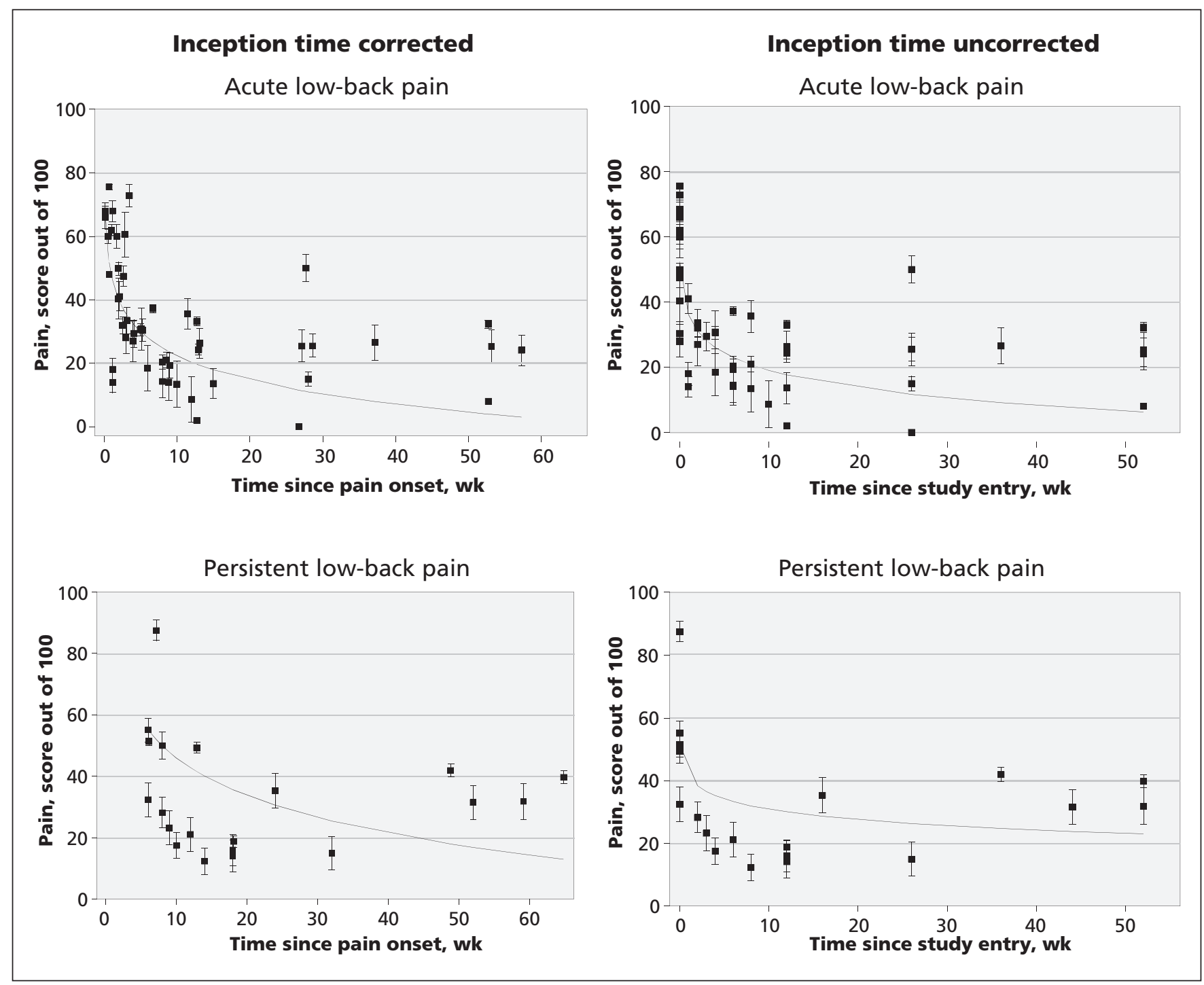

Figure 2: Course of pain in patients with acute and chronic low-back pain. Cohorts are represented by individual data points. 
difference was not statistically significant ( $p=$ 0.2 ). However, the clinical course of pain was more favourable than the clinical course of disability in the persistent pain cohorts $(p=0.002)$.

\section{Recovery from low-back pain}

Recovery was measured in $19(57.6 \%)$ of the included cohorts. Given the heterogeneity of the studies in terms of the definitions of low-back pain, recovery and length of follow-up, it was not possible to pool the data. Most studies reported that the majority of patients with acute low-back pain had recovered by 12 weeks. Among patients with persistent low-back pain, recovery occurred in less than half of the patients at the longest follow-up time. Recovery rate data are presented in Table 4.

\section{Prognostic factors}

Appendix 2 (available at www.cmaj.ca/lookup /suppl/doi:10.1503/cmaj.111271/-/DC1) presents a description of prognostic factors evaluated by each study (when available). A large number of potential prognostic factors were tested, with demographic and clinical characteristics being the most frequently evaluated. Reporting of the strength of association was very inconsistent among the studies, which made it impossible to pool these data.

\section{Interpretation}

The results of our meta-analysis of the course of acute and persistent low-back pain based on data from inception cohort studies are consistent with findings from previous studies of acute low-back pain. Our review confirms the broad finding of previous reviews that the typical course of acute low-back pain is initially favourable: there is a marked reduction in mean pain and disability in the first six weeks. Beyond six weeks, improvement slows and thereafter only small reductions in mean pain and disability are apparent up to one year. By one year, the average levels of pain and disability for acute low-back pain were low (mean pain score [inception time uncorrected] of

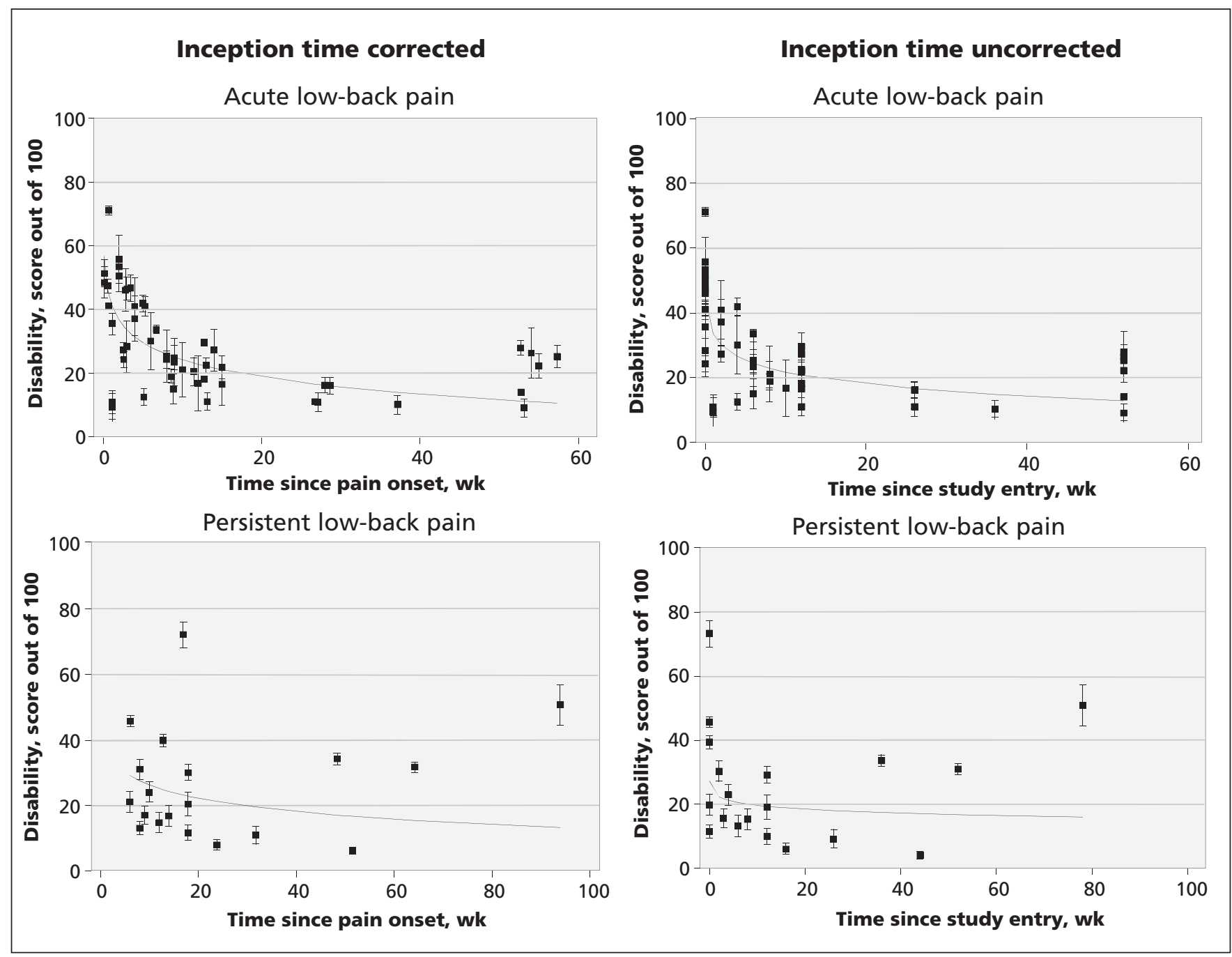

Figure 3: Course of disability in patients with acute and chronic low-back pain. Cohorts are represented by individual data points. 
6 and disability score of 13), suggesting that patients can expect to have minimal pain or disability at one year.

People with persistent low-back pain also experienced substantial improvement in the first six weeks, but there were only very small reductions in average pain and disability between 6 and 52 weeks (mean reductions in pain and disability score [inception time uncorrected] of 10 and 4, respectively). Patients with persistent low-back pain could expect to have moderate levels of pain and disability at 12 months (mean pain and disability scores of 23 and 17, respectively). For both acute and persistent low-back pain, there was moderate between-participant variability in outcomes.

We used a sensitive search strategy, which necessitated screening a large number of titles (28 613 titles screened, 43 eligible articles, number needed to screen $=665$ titles). This means that it is likely that most eligible studies were included in our review. We included only inception cohort studies because this type of design minimizes bias in studies of prognosis. ${ }^{7}$ We were able to pool pain and disability outcomes from most of the eligible cohorts. Unfortunately, six studies did not report continuous measures of pain or disability, and the authors of these studies did not respond to requests to provide data. Therefore, not all studies that collected continuous measures of pain and disability were included in our final analysis.

In this study, pooled estimates of the clinical course of pain and disability were determined using mixed linear models. There are at least two reasons why these data may provide inaccurate prognoses. First, there is obvious between-study heterogeneity. That is, the mean outcomes of some cohorts differ substantially from the pooled estimate. The cause of this heterogeneity is not known, but it could be real (e.g., because of variation in characteristics of particular study cohorts) or due to bias (e.g., high rates of loss to follow-up in some cohorts). A second issue is that there was evidence of a moderate amount of person-to-person variability within each study (which could be due to, for example, initial pain intensity, duration of symptoms, previous episodes, presence or absence of sciatica, personal characteristics and care received). The standard deviations for pain and disability were consistently around 20 . As the outcomes were normally distributed, about onethird of patients would have prognoses that differ by more than 20 points from the study mean. The best way to explore this variability and to generate subject-specific prognoses that take into account suspected prognostic factors would be to perform a meta-analysis using individual patient data. It may be possible to conduct such studies in the future.

Another possible explanation for the improvement of patients over time may be regression to the mean, which is a consequence of random variation over time. Some of the randomness will be "true" variation caused by biological, psychological or sociological mechanisms (e.g., people's pain will fluctuate unpredictably because of their activity levels and mood) and some will be measurement error (because people's self-reports of their pain and disability will not be perfectly precise). It is probably impossible to properly partition out the contributions of these two sources of regression to the mean. But

Table 3: Pooled estimates of mean pain and disability*

\begin{tabular}{|c|c|c|c|c|}
\hline \multirow[b]{2}{*}{ Group } & \multicolumn{2}{|c|}{ Pooled estimate of mean pain $(95 \% \mathrm{Cl})$} & \multicolumn{2}{|c|}{ Pooled estimate of mean disability $(95 \% \mathrm{Cl})$} \\
\hline & $\begin{array}{l}\text { Inception time } \\
\text { uncorrected }\end{array}$ & $\begin{array}{l}\text { Inception time } \\
\text { corrected }\end{array}$ & $\begin{array}{l}\text { Inception time } \\
\text { uncorrected }\end{array}$ & $\begin{array}{l}\text { Inception time } \\
\text { corrected }\end{array}$ \\
\hline \multicolumn{5}{|c|}{ Acute low-back pain } \\
\hline Baseline & $52(48-57)$ & $69(61-78)$ & $45(42-48)$ & $57(52-62)$ \\
\hline 6 wk & $23(21-25)$ & $28(25-31)$ & $24(23-26)$ & $28(26-30)$ \\
\hline 26 wk & $12(9-15)$ & $12(8-15)$ & $16(15-18)$ & $17(15-19)$ \\
\hline $52 \mathrm{wk}$ & $6(3-10)$ & $4(0-9)$ & $13(11-15)$ & $11(9-14)$ \\
\hline \multicolumn{5}{|c|}{ Persistent low-back pain } \\
\hline Baseline & $51(44-59)$ & NAt & $27(24-30)$ & $51(39-63)$ \\
\hline $6 \mathrm{wk}$ & $33(29-38)$ & $55(46-63)$ & $21(19-22)$ & $28(25-31)$ \\
\hline 26 wk & $26(20-33)$ & $29(23-35)$ & $18(16-20)$ & $19(18-21)$ \\
\hline $52 \mathrm{wk}$ & $23(16-30)$ & $17(7-27)$ & $17(14-19)$ & $15(12-18)$ \\
\hline \multicolumn{5}{|c|}{$\begin{array}{l}\text { Note: } \mathrm{Cl}=\text { confidence interval, } \mathrm{NA}=\text { not available. } \\
\text { *All values are expressed in a scale ranging from } 0 \text { (i.e., no pain or disability) to } 100 \text { (i.e., maximum pain or disability). } \\
\text { tThe estimates of baseline values were not obtained for analyses of inception time corrected time for pain outcomes because } \\
\text { this involved extrapolating the fitted curves substantially beyond the range of the data. }\end{array}$} \\
\hline
\end{tabular}


Table 4: Summary of recovery from low back pain

\begin{tabular}{|c|c|c|}
\hline Study & Inception time & Recovery rates \\
\hline Bousema et al. ${ }^{11}$ & 4-7 wk & - After $1 \mathrm{yr}, 32 \%$ had no back pain complaints \\
\hline Carey $^{15}$ & $12-22$ weeks & $\begin{array}{l}\text { - } 33 \% \text { had no functionally limiting symptoms after } 18 \mathrm{mo} \\
\text { - } 16 \% \text { had no back symptoms after } 18 \mathrm{mo}\end{array}$ \\
\hline Costa $^{16}$ & 12 weeks & $\begin{array}{l}\text { - Only } 11 \% \text { of patients had not returned to work in their previous capacity at the onset of chronicity } \\
\text { and, of those } 46 \% \text {, had returned to work by } 12 \text { mo } \\
\text { - The cumulative probability of being pain-free, maintained for one mon, was } 35 \% \text { at } 9 \text { mo and } 42 \% \\
\text { at } 12 \text { mo after onset } \\
\text { - The cumulative probability of having no disability, maintained for one mo, was } 39 \% \text { at } 9 \text { mo and } \\
47 \% \text { at } 12 \text { mo after onset } \\
\text { - The cumulative probability of being completely recovered (pain-free, no disability and returned to } \\
\text { prior work status maintained for one mo) was } 35 \% \text { at } 9 \text { mo and } 41 \% \text { at } 12 \text { mo after onset of } \\
\text { chronic pain }\end{array}$ \\
\hline Coste et al. ${ }^{18}$ & $<72 \mathrm{~h}$ & $\begin{array}{l}\text { - } 87 \%(95 \% \mathrm{Cl} 79 \%-95 \%) \text { had recovered in } 30 \mathrm{~d} \\
\text { - } 95 \%(95 \% \mathrm{Cl} 91 \%-100 \%) \text { had recovered in } 3 \mathrm{mo}\end{array}$ \\
\hline $\begin{array}{l}\text { Epping-Jordan et al. }{ }^{19} \\
\text { Shaw et al. }{ }^{20} \\
\text { Wahlgren et al. } .^{21} \\
\text { Williams et al. }{ }^{22}\end{array}$ & $6-10 w k$ & $\begin{array}{l}\text { - } 54 \% \text { improved by } 6 \mathrm{mo} \\
\text { - } 67 \% \text { improved by } 12 \mathrm{mo}\end{array}$ \\
\hline Ferguson et al..$^{24,25}$ & $<4 \mathrm{wk}$ & $\begin{array}{l}\text { - } 68 \% \text { of patients were not impaired according to functional performance, and } 80 \% \text { were not } \\
\text { impaired in terms of pain by } 14 \text { to } 18 \mathrm{wk}\end{array}$ \\
\hline Grotle et al. ${ }^{2,28}$ & $<3 w k$ & $\begin{array}{l}\text { - } 76 \% \text { had recovered }(\mathrm{RMDQ}<4) \text { after both } 4 \mathrm{wk} \text { and } 3 \mathrm{mo} \\
\text { - } 83 \% \text { of patients had recovered fully from their disability after } 1 \mathrm{yr}(\mathrm{RMDQ}<4)\end{array}$ \\
\hline Gurcay et al. ${ }^{29}$ & $<3 w k$ & $\begin{array}{l}\text { - } 27 \% \text { recovered in the first wk } \\
\text { - } 31 \% \text { recovered in the second wk } \\
\text { - } 23 \% \text { recovered in the fourth wk } \\
\text { - } 10 \% \text { recovered at the eighth wk } \\
\text { - } 1 \% \text { recovered after } 12 \text { wk } \\
\text { - } 9 \% \text { developed chronic low-back pain }\end{array}$ \\
\hline Henschke et al. ${ }^{3}$ & $>24 \mathrm{~h}$ to $<2 \mathrm{wk}$ & $\begin{array}{l}\text { - The cumulative probability of returning to work with pre-back pain work status and duties for those } \\
\text { who reduced their work status at baseline because of low-back pain was } 80 \% \text { at } 6 \mathrm{wk}, 83 \% \text { at } 12 \mathrm{wk} \\
\text { and } 90 \% \text { by } 1 \mathrm{yr} \\
\text { - The cumulative probability of having no disability was } 55 \% \text { at } 6 \mathrm{wk}, 73 \% \text { by } 12 \mathrm{wk} \text { and } 83 \% \text { by } 1 \mathrm{yr} \\
\text { - The cumulative probability of being pain free was } 39 \% \text { by } 6 \mathrm{wk}, 58 \% \text { by } 12 \mathrm{wk} \text { and } 73 \% \text { by } 1 \mathrm{yr} \\
\text { - The cumulative probability of being completely recovered was } 39 \% \text { by } 6 \mathrm{wk}, 57 \% \text { by } \\
12 \mathrm{wk} \text { and } 72 \% \text { by } 1 \mathrm{y}\end{array}$ \\
\hline Klenerman et al..$^{34}$ & $<1 \mathrm{wk}$ & $\begin{array}{l}\text { - } 21 \% \text { were classified as having no pain at } 12 \mathrm{mo} \\
\text { - } 28 \% \text { were classified as having no intermittent pain at } 12 \mathrm{mo} \\
\text { - } 93 \% \text { were classified as not having constant pain at } 12 \mathrm{mo}\end{array}$ \\
\hline Koleck et al. ${ }^{35}$ & $10-90 d$ & $\begin{array}{l}\text { - } 67 \% \text { of patients were classified as improved after } 1 \mathrm{yr} \\
\text { - } 67 \% \text { were classified as not having chronic low-back pain after } 1 \mathrm{yr}\end{array}$ \\
\hline Melloh et al. ${ }^{38}$ & $<12 w k$ & $\begin{array}{l}\text { - } 75 \% \text { were classified as nonpersistent low-back pain at } 6 \mathrm{wk} \\
\text { - } 25 \% \text { were classified as persistent low-back pain at } 6 \mathrm{wk}\end{array}$ \\
\hline Poiraudeau et al. ${ }^{39}$ & $4-12 w k$ & $\begin{array}{l}\text { - } 60 \% \text { did not have persistent low-back pain at } 3 \text { mo } \\
\text { - } 59 \% \text { did not use sick leave during the } 3 \text { mo period } \\
\text { - } 83 \% \text { had returned to work at } 3 \text { mo }\end{array}$ \\
\hline $\begin{array}{l}\text { Schiottz-Christensen et } \\
\text { al. }^{41}\end{array}$ & $<14 \mathrm{~d}$ & $\begin{array}{l}\text { - } 84 \%(95 \% \mathrm{Cl} 80 \%-87 \%) \text { of patients functionally recovered at } 6 \mathrm{mo} \\
\text { - } 92 \%(95 \% \mathrm{Cl} 89 \%-94 \%) \text { functionally recovered at } 12 \mathrm{mo} \\
\text { - } 47 \% \text { of patients completely recovered at } 6 \text { and } 12 \mathrm{mo}\end{array}$ \\
\hline Valat et al. ${ }^{50}$ & $<1 \mathrm{wk}$ & - $61.3 \%$ had fully recovered at $7 \mathrm{wk}$ \\
\hline
\end{tabular}


for practical purposes, it is probably not necessary. The data have a useful pragmatic interpretation because they indicate the time course of self-reported reductions in pain and disability, even though the cause of the reduction is not known.

To our knowledge, there has been only one previous systematic review that has quantitatively synthesized study data on the clinical course of low-back pain. ${ }^{5}$ A strength of our review is that we retrieved more studies than the previous review, and we used an analysis approach that could accommodate outcomes measured at different times. We were thus able to provide more precise estimates of the course of acute low-back pain. The availability of more cohorts also made it practical to not include data from randomized controlled trials. Typically, the inclusion and exclusion criteria in randomized controlled trials are more restrictive than those used in cohort studies, ${ }^{7}$ which means that cohort studies are likely to provide more generalizable estimates of prognosis. Unlike the previous quantitative synthesis that only considered the clinical course of acute low-back pain, ${ }^{5}$ we also examined the clinical course of persistent low-back pain.

Although we acknowledge that the identification of prognostic factors is important, it is a challenge to summarize this information because there is great variability in the methods used to measure putative prognostic factors, build prognostic models, and quantify and report prognostic value..$^{6,51}$ These difficulties were also observed in previous systematic reviews of acute low-back pain ${ }^{4,5}$ and whiplash. ${ }^{9}$ One systematic review on the course of acute low-back pain identified distress, previous episodes of low-back pain and job satisfaction as likely prognostic factors. ${ }^{5}$ The most recent review of prognostic factors for the development of persistent low-back pain ${ }^{4}$ found that maladaptive pain coping behaviours, nonorganic signs, functional impairment, general health status and presence of psychiatric comorbidities were the most important prognostic factors.

\section{Limitations}

Only a small proportion of eligible studies explicitly excluded patients with leg pain or sciatica, ${ }^{17,18}$ while most studies either did not provide any information on this distinction (12 cohorts) or included some patients with leg pain or sciatica (19 cohorts). It was common for authors to refer to the presence of leg pain as sciatica without differentiating whether the pain was somatic or radicular. Therefore, it is possible that our estimates of the prognosis of nonspecific low-back pain may be influenced by the inclusion of some patients with radicular pain.
We classified studies as acute or persistent based on the median or mean duration of symptoms when provided or the midpoint of the range if not available. It is possible that some studies with means or medians close to our threshold of six weeks could be similar to other cohorts with a different classification. Only one study ${ }^{39}$ that provided accurate information on the duration of symptoms had a mean duration within one week of our threshold. Studies including patients typically considered to have subacute low-back pain (6-12 weeks) were included in our persistent group. Although it is possible that these patients have a more favourable prognosis, the reasonably consistent pattern of results in our persistent cohorts suggests this was not the case.

\section{Conclusion}

We found that patients with acute or persistent low-back pain improved markedly in the first six weeks, but beyond this time improvement slowed. Even at one year, patients had low to moderate levels of pain and disability. Future research is needed to make more precise recommendations on the standardization of recovery definitions of a low-back pain episode and to develop an optimal search strategy to retrieve prognostic studies. These improvements in research will facilitate the development of future prognostic systematic reviews.

\section{References}

1. van Tulder M, Becker A, Bekkering T, et al. Chapter 3. European guidelines for the management of acute nonspecific low-back pain in primary care. Eur Spine $J$ 2006;15(Suppl 2):S169-91.

2. Grotle M, Brox JI, Veierød MB, et al. Clinical course and prognostic factors in acute low-back pain: patients consulting primary care for the first time. Spine (Phila Pa 1976) 2005;30:976-82.

3. Henschke N, Maher CG, Refshauge KM, et al. Prognosis in patients with recent onset low-back pain in Australian primary care: inception cohort study. BMJ 2008;337:a171.

4. Chou R, Shekelle P. Will this patient develop persistent disabling low-back pain? JAMA 2010;303:1295-302.

5. Pengel LH, Herbert RD, Maher CG, et al. Acute low-back pain: systematic review of its prognosis. BMJ 2003;327:323.

6. Altman DG. Systematic reviews of evaluations of prognostic variables. BMJ 2001;323:224-8.

7. Grobbee DE, Hoes AW. Clinical epidemiology: principles, methods, and applications for clinical research. Burlingotn (MA): Jones and Bartlett; 2009.

8. Airaksinen O, Brox JI, Cedraschi C, et al. Chapter 4. European guidelines for the management of chronic nonspecific low-back pain. Eur Spine J 2006;15(Suppl 2):S192-300.

9. Kamper SJ, Rebbeck TJ, Maher CG, et al. Course and prognostic factors of whiplash: a systematic review and meta-analysis. Pain 2008;138:617-29.

10. Bakker EW, Verhagen AP, Lucas C, et al. Spinal mechanical load: A predictor of persistent low-back pain? A prospective cohort study. Eur Spine J 2007;16:933-41.

11. Bousema EJ, Verbunt JA, Seelen HA, et al. Disuse and physical deconditioning in the first year after the onset of back pain. Pain 2007;130:279-86.

12. Breen AC, Carr E, Langworthy JE, et al. Back pain outcomes in primary care following a practice improvement intervention: a prospective cohort study. BMC Musculoskelet Disord 2011; 12:28.

13. Carey TS, Garrett J, Jackman A, et al. The outcomes and costs of care for acute low-back pain among patients seen by primary care practitioners, chiropractors, and orthopedic surgeons. The North 
Carolina Back Pain Project. N Engl J Med 1995;333:913-7.

14. Sundararajan V, Konrad TR, Garrett J, et al. Patterns and determinants of multiple provider use in patients with acute low-back pain. J Gen Intern Med 1998;13:528-33.

15. Carey TS, Garrett JM, Jackman AM. Beyond the good prognosis. Examination of an inception cohort of patients with chronic low-back pain. Spine (Phila Pa 1976) 2000;25:115-20.

16. Costa LC, Maher CG, McAuley JH, et al. Prognosis for patient with chronic low-back pain: inception cohort study. $B M J$ 2009;339:b3829.

17. Coste J, Delecoeuillerie G, Cohen de Lara, et al. Clinical course and prognostic factors in acute low-back pain: an inception cohort study in primary care practice. BMJ 1994;308:577-80.

18. Coste J, Lefrancois G, Guillemin F, et al. Prognosis and quality of life in patients with acute low-back pain: insights from a comprehensive inception cohort study. Arthritis Rheum 2004;51: 168-76.

19. Epping-Jordan JE, Wahlgren DR, Williams RA, et al. Transition to chronic pain in men with low-back pain: predictive relationships among pain intensity, disability, and depressive symptoms. Health Psychol 1998;17:421-7.

20. Shaw WS, Means-Christensen A, Slater MA, et al. Shared and independent associations of psychosocial factors on work status among men with subacute low-back pain. Clin J Pain 2007;23: 409-16.

21. Wahlgren DR, Atkinson JH, Epping-Jordan JE, et al. One-year follow-up of first onset low-back pain. Pain 1997;73:213-21.

22. Williams RA, Pruitt SD, Doctor JN, et al. The contribution of job satisfaction to the transition from acute to chronic low-back pain. Arch Phys Med Rehabil 1998;79:366-74.

23. Faber E, Burdorf A, Bierma-Zeinstra SM, et al. Determinants for improvement in different back pain measures and their influence on the duration of sickness absence. Spine 2006;31:1477-83.

24. Ferguson SA, Gupta P, Marras WS, et al. Predicting recovery using continuous low-back pain outcome measures. Spine $J$ 2001; 1:57-65

25. Ferguson SA, Marras WS, Gupta P. Longitudinal quantitative measures of the natural course of low-back pain recovery. Spine (Phila Pa 1976) 2000;25:1950-6.

26. Gatchel RJ, Polatin PB, Kinney RK, et al. Predicting outcome of chronic back pain using clinical predictors of psychopathology: a prospective analysis. Health Psychol 1995;14:415-20.

27. Gatchel RJ, Polatin PB, Mayer TG, et al. The dominant role of psychosocial risk factors in the development of chronic lowback pain disability. Spine 1995;20:2702-9.

28. Grotle M, Brox JI, Glomsrod B, et al. Prognostic factors in firsttime care seekers due to acute low-back pain. Eur J Pain 2007; 11:290-8.

29. Gurcay E, Bal A, Eksioglu E, et al. Acute low-back pain: clinica course and prognostic factors. Disabil Rehabil 2009;31:840-5.

30. Hasenbring MI, Hallner D, Klasen B, et al. Pain-related avoidance versus endurance in primary care patients with subacute back pain: psychological characteristics and outcome at a 6month follow-up. Pain 2012;153:211-7.

31. Hazard RG, Haugh LD, Reid S, et al. Early prediction of chronic disability after occupational low-back injury. Spine (Phila Pa 1976) 1996;21:945-51

32. Reid S, Haugh LD, Hazard RG, et al. Occupational low-back pain: recovery curves and factors associated with disability. $J$ Occup Rehabil 1997;7:1-14.

33. Heneweer H, Aufdemkampe G, van Tulder MW, et al. Psychosocial variables in patients with (sub)acute low-back pain: an inception cohort in primary care physical therapy in The Netherlands. Spine (Phila Pa 1976) 2007;32:586-92.

34. Klenerman L, Slade PD, Stanley IM, et al. The prediction of chronicity in patients with an acute attack of low-back pain in a general practice setting. Spine 1995;20:478-84

35. Koleck M, Mazaux JM, Rascle N, et al. Psycho-social factors and coping strategies as predictors of chronic evolution and quality of life in patients with low-back pain: a prospective study. Eur J Pain 2006;10:1-11

36. Kovacs FM, Abraira V, Zamora J, et al. The transition from acute to subacute and chronic low-back pain: a study based on determinants of quality of life and prediction of chronic disability. Spine (Phila Pa 1976) 2005;30:1786-92.

37. Lehmann TR, Spratt KF, Lehmann KK, et al. Predicting longterm disability in low-back injured workers presenting to a spine consultant. Spine 1993;18:1103-12.

38. Melloh M, Elfering A, Egli Presland C, et al. Predicting the transition from acute to persistent low-back pain. Occup Med (Lond)
2011;61:127-31

39. Poiraudeau S, Rannou F, Le Henanff A, et al. Outcome of subacute low-back pain: influence of patients' and rheumatologists characteristics. Rheumatology (Oxford) 2006;45:718-23.

40. Reeser JC, Wiegmann SM, Hoover N, et al. Treatment of acute low-back pain in Wisconsin: results of the State Medical Society's Medical Outcomes Research Project. WMJ 2001;100:35-42.

41. Schiøttz-Christensen B, Nielsen GL, Hansen VK, et al. Longterm prognosis of acute low-back pain in patients seen in general practice: a 1-year prospective follow-up study. Fam Pract 1999; 16:223-32.

42. Shaw WS, Pransky G, Patterson W, et al. Patient clusters in acute, work-related back pain based on patterns of disability risk factors. J Occup Environ Med 2007;49:185-93.

43. Shaw WS, Pransky G, Patterson W, et al. Early disability risk factors for low-back pain assessed at outpatient occupational health clinics. Spine (Phila Pa 1976) 2005;30:572-80.

44. Shaw WS, Pransky G, Winters T. The Back Disability Risk Questionnaire for work-related, acute back pain: prediction of unresolved problems at 3-month follow-up. J Occup Environ Med 2009;51:185-94

45. Sieben JM, Vlaeyen JW, Tuerlinckx S, et al. Pain-related fear in acute low-back pain: the first two weeks of a new episode. Eur J Pain 2002:6:229-37.

46. Sieben JM, Vlaeyen JW, Portegijs PJ, et al. A longitudinal study on the predictive validity of the fear-avoidance model in lowback pain. Pain 2005; 117:162-70.

47. Suri P, Rainville J, Fitzmaurice GM, et al. Acute low-back pain is marked by variability: An internet-based pilot study. $B M C$ Musculoskelet Disord 2011;12:220.

48. Swinkels-Meewisse IE, Roelofs J, Schouten EG, et al. Fear of movement/(re)injury predicting chronic disabling low-back pain: a prospective inception cohort study. Spine (Phila Pa 1976) 2006;31:658-64

49. Thomas JS, France CR. The relationship between pain-related fear and lumbar flexion during natural recovery from low-back pain. Eur Spine J 2008;17:97-103.

50. Valat JP, Goupille P, Rozenberg S, et al. Acute low-back pain: predictive index of chronicity from a cohort of 2487 subjects. Joint Bone Spine 2000:456-61.

51. Altman DG. Systematic reviews of evaluations of prognostic variables. In: Egger M, editor. Systematic reviews in health care. London (UK): BMJ Books; 2001.

Affiliations: From the George Institute for Global Health (Menezes Costa, Maher, Herbert), the University of Sydney; the Faculty of Human Sciences (Hancock), Macquarie University; the Faculty of Health Sciences (Hancock), University of Sydney; Prince of Wales Medical Research Institute (McAuley), Sydney, Australia; and the Masters in Physical Therapy (Menezes Costa, Costa), Universidade Cidade de São Paulo, São Paulo, Brazil.

Contributors: All authors contributed to the design of the study. Luciola Menezes Costa and Leonardo Costa conducted the searches, located and selected the studies, assessed the quality of the studies, extracted and interpreted the data and wrote the manuscript. Mark Hancock and Christopher Maher double-checked the data from eligible studies. Robert Herbert analyzed the data. Christopher Maher, Mark Hancock, James McAuley and Robert Herbert interpreted the data, advised on statistical analysis and revised the manuscript. Christopher Maher had full access to all of the data in the study and takes responsibility for the integrity of the data and the accuracy of the data analysis. All authors approved the final version of the manuscript submitted for publication.

Funding: Luciola Menezes Costa was supported by a $\mathrm{PhD}$ scholarship from the University of Sydney during the course of this study. Christopher Maher is supported by the Australia Research Council and Robert Herbert is supported by Australia's National Health and Medical Research Council. Leonardo Costa is supported by Fundação de Amparo a Pesquisa do Estado de São Paulo, Brazil. There was no specific funding for this study. 